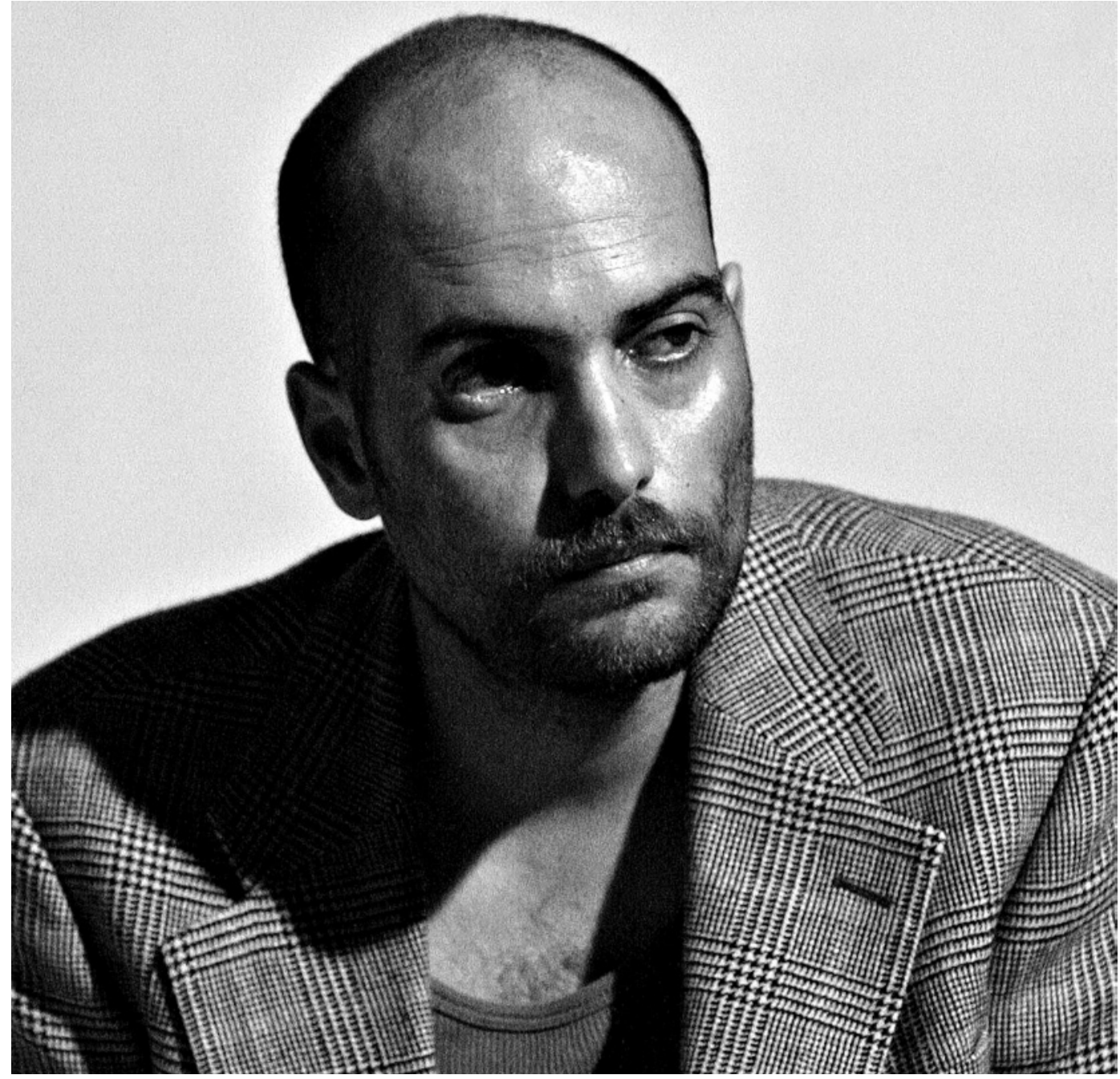

Buno Bravo, 2008 fot. Sérgio Lemos.

\title{
Bruno Bravo
}

\section{Entrar lá dentro e ver até onde aquilo vai}

\section{Ana Bigotte Vieira, Emília Costa e Miguel Castro Caldas ${ }^{1}$}

A propósito de teatro e da criação de 'espaços comuns' na cidade de Lisboa², conversámos com Bruno Bravo em Julho de 2010 e repetimos a conversa em Julho de 2011. Interessava-nos, por um lado, abordar a sua estética como encenador e, por outro, a história dos Primeiros Sintomas, chamando a atenção para projectos colectivos a contracorrente como são as Curtas Primeiros Sintomas ou as Leituras não encenadas. No seu trabalho de encenação foi sobretudo a elegância da sua recusa subtil (mas total) do psicologismo o que nos chamou a atenção, aquilo a que chamámos uma certa 'descrença' na personagem. Nas suas encenações as personagens 'são' o que dizem, num trabalho mais de 'superficie' (ler o texto) do que de 'profundidade' (procurar a psicologia), muitas vezes ajudado pelos textos originais de Miguel Castro Caldas (cuja escrita se caracteriza pelo jogo com a imanência das palavras e a sua capacidade de gerar imagens e sentidos sem a mediação de personagens psicológicas). Bruno Bravo estende, porém, esta abordagem aos textos considerados 'clássicos' sem perder uma certa 'teatralidade', antes pelo contrário, insistindo nela. Conjuntamente, as suas encenações têm-se caracterizado por uma espacialidade que resulta da transposição para o espaço das relações entre as personagens 'esticadas ao máximo' - explicitando tensões -, por uma certa artificialidade na representação, e pela utilização de recursos teatrais mínimos e explícitos para espectáculos curtos.

Quanto às Curtas Primeiros Sintomas ou às Leituras não encenadas, estes são projectos que consideramos 'a contracorrente' por conseguirem criar um espaço fora das pressões de "excelência" e de "sucesso", ao mesmo tempo que se subtraem às expectativas em relação à "obra", ao percurso (coerente) do "criador" e à concordância obra/estilo do equipamento onde se apresenta. Nas Leituras, como nas Curtas, as pessoas puderam experimentar fazer coisas fora dos seus "papéis sociais" (actores a encenar e escritores a representar). E, no Verão de 2011, em que tanta gente estava sem trabalho, estes acontecimentos constituiram-se num 'espaço de encontro', numa altura em que a retórica mainstream e as condições socioeconómicas promoviam o isolamento, a competição e o pessimismo. 0 novo espaço dos Primeiros Sintomas à Ribeira é, pode dizer-se, um ponto de encontro.

A versão aqui transcrita corresponde à junção e edição de duas conversas. A primeira teve lugar em Julho de 2010, durante as CURTAS Primeiros Sintomas - mostra de que estiveram presentes Ana Bigotte Vieira, Migue Castro Caldas e Bruno Bravo. A segunda teve lugar um ano depois, em Julho de 2011, durante as Leituras não encenadas Primeiros Sintomas e estiveram presentes Ana Bigotte Vieira, Emília Costa e Bruno Bravo. 
As rosas suicidam-se a partir de Greguerias de Ramón Gómez de La Serna enc. Bruno Bravo e Élvio Camacho, Primeiros Sintomas, 2001 (Élvio Camacho e Bruno Bravo), fot. desconhecido.
Quando é que começaste a interessar-te por teatro? No secundário, na escola Gil Vicente, que oferecia como opção a cadeira de Teatro, no nono ano. A professora era a Ana Vinagre que me deu imensa liberdade. Escrevia, encenava e actuava com os meus colegas. 0 Miguel Castro Caldas - éramos da mesma turma - chegou a participar como actor num desses exercícios (risos). Foi aliás o Miguel que me convenceu a ir para a área de teatro. "É pá, tens é de ir para teatro", dizia-me ele, já com aquele ar fatalista. Antes disso queria ser jornalista. Ou melhor, repórter, como o Tintim.

\section{Quais são as tuas principais influências?}

Tenho várias. A mais importante, as pessoas com quem trabalho. Eu não escolho os actores em função dos traços fisionómicos ou de carácter que, à partida, se adequariam mais àquela personagem. Claro que também posso ter isso em conta, mas a minha escolha é feita, sobretudo, em função de serem pessoas com quem me interessa trabalhar. Por exemplo, no espectáculo As bodas de Figaro, de Migue Castro Caldas, a partir de Beaumarchais, queria trabalhar com o Dinis Gomes e, por isso, a escolha foi automática. E isso é uma influência muito prática, as minhas influências estão sempre muito ligadas ao presente e ao trabalho.

0 Jorge Silva Melo foi, também, uma figura importante na minha formação. Comecei a trabalhar como actor nos Artistas Unidos e o Jorge, nos ensaios, fazia-nos ver o teatro de uma maneira muito diferente, muito prática. A personagem ganhava outras dimensões para além da tradicional composição psicológica (e moral). Éramos também nós, actores, que estávamos em cena. No espectáculo 0 fim ou tende misericórdia de nós, começámos logo, desde o primeiro dia, com ensaios corridos, ainda com o texto na mão, e era sempre do princípio até ao fim - comigo só fez um ensaio parcelar. Num certo sentido, o espectáculo ia crescendo sempre todo junto e ele ia apagando. 0 Jorge é um encenador que usa mais a borracha

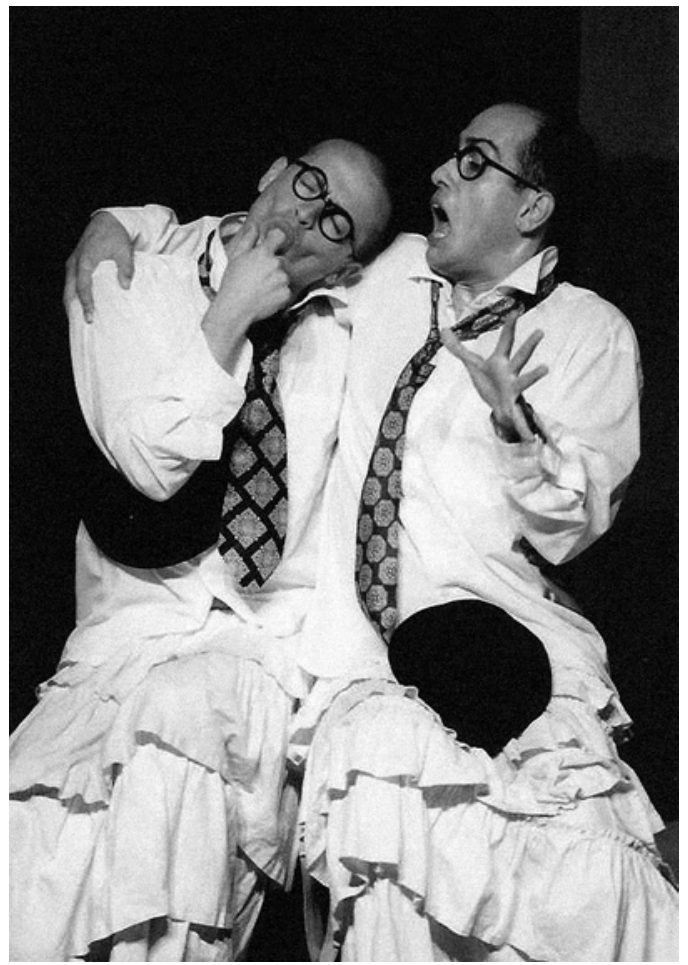

do que o lápis. 0 actor não era só um executante. E isso, na altura, marcou-me. Acho que sou uma espécie de vampiro. Ainda hoje não me sinto confortável a dirigir: tenho dificuldade em apontar linhas muito estreitas. Trabalho melhor com aquilo que o actor tem, para depois o provocar.

Depois tenho referências dispersas. Na realidade tudo me influencia, tudo tem esse potencial. 0 teatro é feito de tanta coisa... Peter Brook, sobretudo na altura em que andava no Conservatório, Peter Stein, o Wooster Group... Depois o cinema, Dreyer, Bergman, David Lynch... A música, muito a música, agora ando com a mania da ópera. Tenho uma paixão, ainda não correspondida, pelos Gregos, pelas tragédias. Tive também a experiência do Conservatório. Apanhei toda uma maneira muito antiga de ver o teatro, mas que, precisamente por isso, por contraste, nos obrigava (a mim e aos outros) a pensar e a combater aquilo. 0 Jorge Silva Melo funcionou como uma espécie de antídoto à minha experiência como aluno no Conservatório.

Houve alguma coisa nessa "escola antiga" que, apesar de tudo, até serviu?

Claro. Tive alguns professores muito bons. Tudo serviu porque foi uma maneira de estar vários anos seguidos a fazer teatro, bom ou mau... mas sempre a lidar com teatro, teve este principio de focalização. Depois, o ambiente da turma, as pessoas que conheci na altura e com quem ainda hoje trabalho. Os Primeiros Sintomas formaram-se também com muitos desses colegas, a Sandra Faleiro, hoje minha mulher, a Raquel Dias, o Peter Michael. E há pouco tempo trabalhei com o Miguel Loureiro, que também foi da minha turma.

o Conservatório tem uma coisa muito boa que é uma maneira muito directa de se entrar no "meio teatral" em Portugal. E como se trata de um meio muito pequenino, tu entras e começas logo a perceber uma série de coisas, ainda hoje isso acontece... 


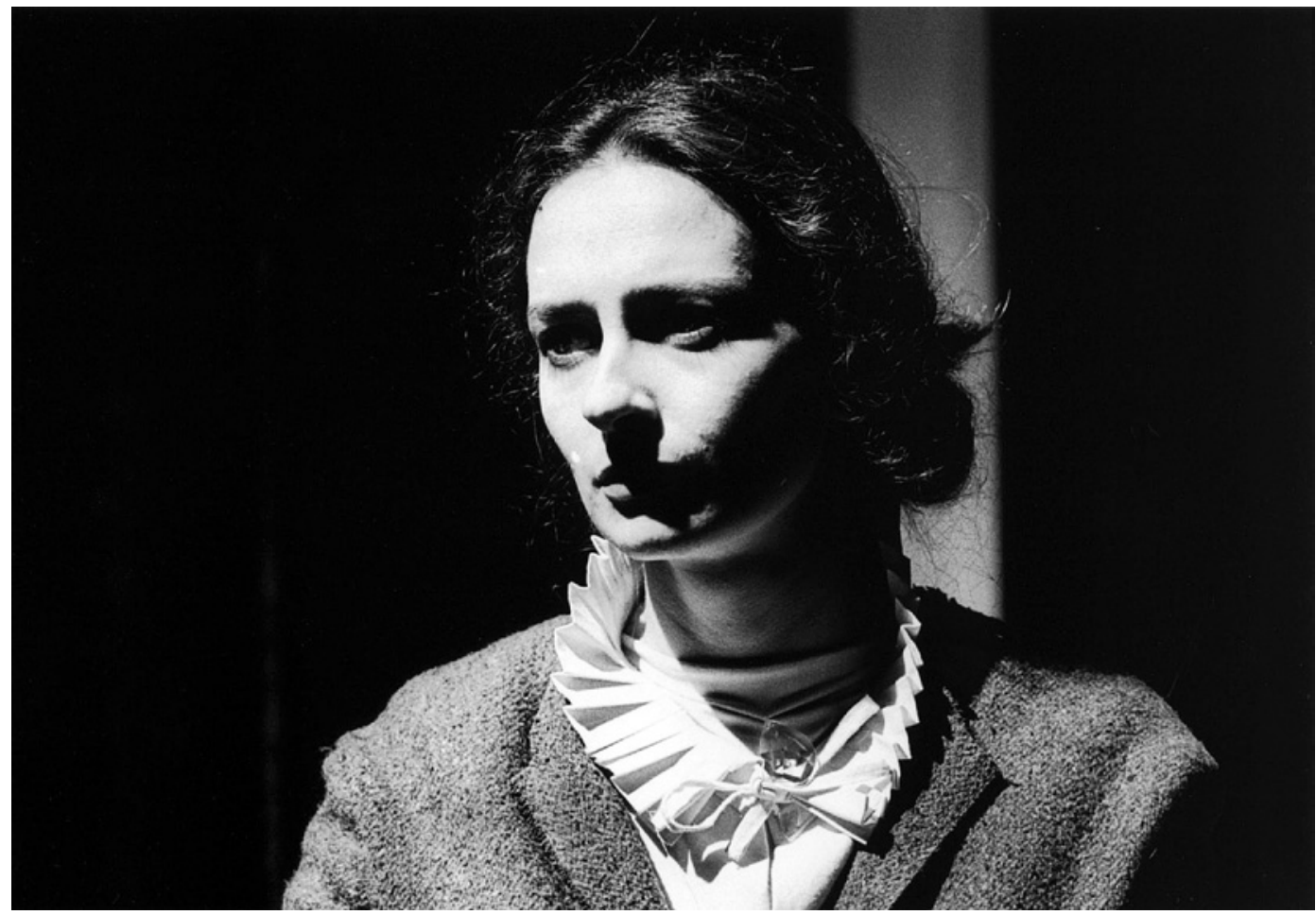

Do ponto de vista pedagógico era muito fraco, porque apanhei uma época que representou, de certo modo, os últimos anos da "velha guarda". Uma ideia muito antiga de teatro, um teatro muito fechado, muito isolado. Nós como estudantes éramos muito contestatários, fazíamos greves. Foi um percurso dificil. Chumbei duas vezes, um desgosto para os meus pais. Estive quase a desistir. A Sandra é que me convenceu a continuar, insistiu muito para que eu entrasse no Bosque de leite, o espectáculo onde me estreei. Na altura éramos só grandes amigos. Depois os Artistas Unidos...

\section{$\mathrm{Na}$ altura, o João Fiadeiro estava a trabalhar com o} Jorge Silva Melo?

Sim, conheci-o nos Artistas Unidos, dava assistência ao Jorge Silva Melo no movimento. Convidou-me para trabalhar com ele num espectáculo de dança, Vidas silenciosas. Foi um ano incrivel. E também me influenciou.

\section{Já fazia Composição em Tempo Real (CTR)?}

Já. Nós fazíamos improvisações de seis, sete horas, sem parar. Se tínhamos de ir à casa de banho tinha de ser dentro da improvisação, podiamos comer, mas tinha de ser naquilo. É uma coisa que hoje em dia já não me faz tanto sentido, não trabalho assim, mas na altura marcoume, era uma experiência muito interessante. 0 Miguel (Castro Caldas) falou-me de um treino no Karaté em que se está três horas a aquecer, aquilo a que se chama "partir o corpo", para depois, quando fores treinar, estares de tal maneira cansado que o corpo fica mais desperto e reage melhor. Estas longas improvisações tinham coisas parecidas: às vezes durante quatro horas não se aproveitava nada, mas depois surgiam uns minutos brilhantes. 0 pensamento entra noutra lógica.

A CTR por vezes cria resultados espaciais fascinantes: as coisas que acontecem "têm" de acontecer. É muito particular $\mathrm{e}$, como há tantas regras, fica tudo mais claro.

Sim. Mas há uma diferença. Eu, por exemplo, gosto de trabalhar num ambiente meio caótico. Caótico no sentido de não sabermos bem onde estamos e de não haver necessidade de se explicar tudo. Nem eu consigo pegar numa peça e dizer: "isto é isto e isto e isto". Mas, por outro lado, dependo de uma certa disciplina, sou incapaz de partir ou de trabalhar a partir do zero.

Partes de uma ideia, de um conceito, de um texto? Em geral, de um texto ou de uma ideia de texto. Mas a maior parte das ideias vão surgindo à medida dos ensaios. No entanto, o conceito está lá e o desafio é descobrir-Ihe a forma.

\section{Foste aluno do João Mota?}

Fui. Um mestre como professor. Dava aulas ao Primeiro Ano. Era de uma ternura e de uma violência impressionantes. 0 João Brites também me marcou. Mas, no geral, era tudo muito desinteressante, a maior parte das coisas era ensinada segundo "chavões". Na altura, não ligava nenhuma a Brecht, por exemplo, porque me parecia antigo e politizado, nem a Tchekov que parecia ainda mais antigo, do século passado! (risos) Era tudo uma misturada, teoria e prática, e tudo com fórmulas muito estanques. muito pela cartilha. Actualmente, acho que Brecht e Tchekov estão "à nossa frente" em muita coisa. Agora, passados estes anos, é que estou a descobrir a dimensão que têm.

\section{Também davam lbsen?}

Sim, "passávamos por"... Era um programa de reportório. A tragédia, a comédia, o realismo e o naturalismo. Gil Vicente também. No meio disto tudo, claro que o João Mota me soava como absolutamente incrivel e o Peter Brook ainda mais incrivel e, quando entrei nos Artistas 


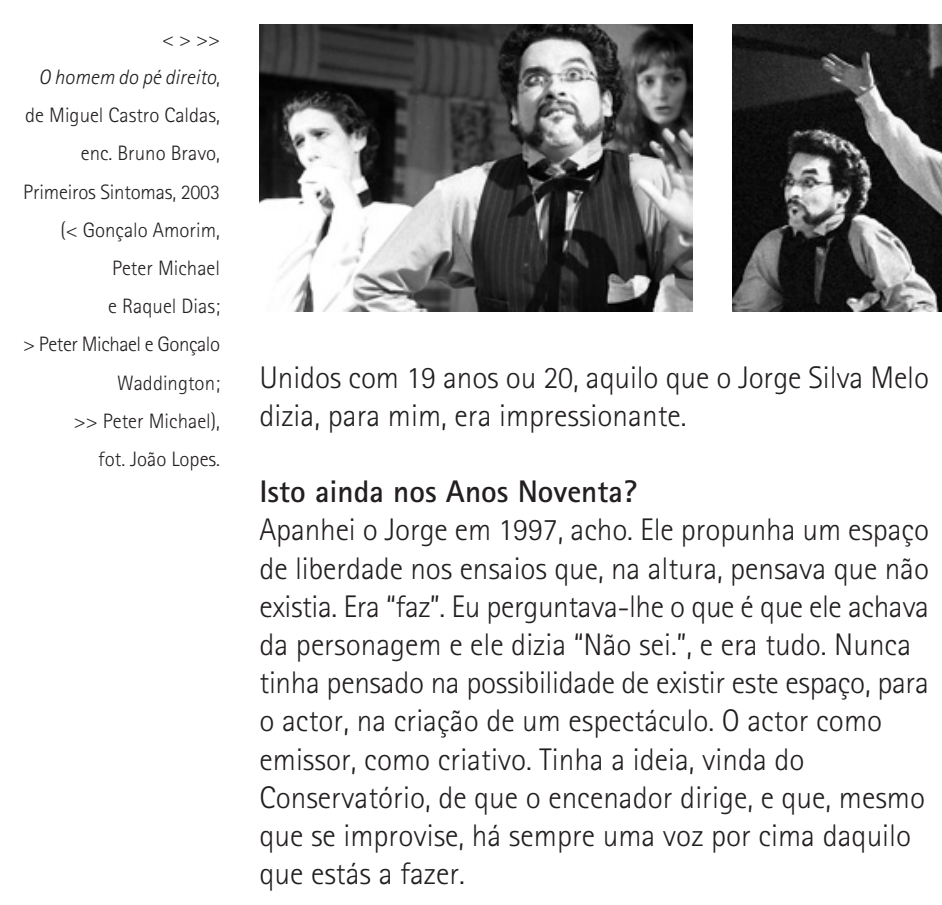

Há algumas semelhanças entre o modo de encenar do Jorge Silva Melo e o teu? Ambos encenando como alguém que vai dando umas pistas e que vai apagando aqui e ali?

Talvez. Não sei se o Jorge Silva Melo ainda encena do mesmo modo. Eu preocupo-me muito em trabalhar com todos numa relação horizontal. E o trabalho vai-se escrevendo em cena. Às vezes, partimos já com algumas escolhas feitas. N' A boda já sabíamos que só íamos ter uma mesa em cena... Continuo a ver o teatro como um imenso diálogo entre os vários criativos das diferentes áreas do espectáculo à procura de um objecto comum Para que isso aconteça é necessária uma grande disciplina. Uma das coisas que mais me estimula no teatro é a possibilidade de se ser um individuo num colectivo, e o modo como o individual e o colectivo coabitam. Nos ensaios, às vezes, sugiro certas coisas e os actores depois devolvem-me quase o seu contrário. Outras vezes, descobres uma pista e depois persegues essa pista - no fundo, é uma perseguição o que nós fazemos, é isso que me estimula, é assim que gosto de trabalhar. Claro que há génios que trabalham, como o Bob Wilson, já com uma ideia predefinida. Mas não há um modelo estanque de como encenar, não digo que encenar "seja" assim como eu faço, mas é deste modo que, cada vez mais, gosto de trabalhar.

\section{"Marcas" espaços e defines tempos?}

Evito. 0 meu ideal de encenação é conseguir não dizer uma palavra durante os ensaios até à estreia. Encenar como só ver e ouvir. Mas muitas vezes ainda digo "experimenta sentar-te" ou "olha para ali", geralmente numa fase já avançada de ensaios. Os melhores para marcar espaços e definir tempos são os actores. Aliás, são os únicos a quem compete essa função. A direç̧ão de actores é uma descoberta conjunta do espaço e dos tempos. Depois os actores são todos diferentes. A relação não é a mesma. Já trabalhei com actores dependentes de direcção, e actores a quem mais vale não dizer nada. Doume bem com estes dois géneros.

Qual é a diferença entre trabalhar um texto do Miguel Castro Caldas e, por exemplo, um texto de Ibsen, com personagens psicologicamente bem definidas?

Muitas diferenças, claro. A maior e mais importante de todas é que um está vivo e o outro já morreu. (risos) É claro que são textos diferentes, que propõem coisas muito diferentes, mas, no fundo, o princípio é o mesmo. Com Ibsen, o texto com que começamos os ensaios em princípio é o texto da estreia. Com o Miguel isso não acontece, pois ele vai reescrevendo à medida dos ensaios. Quanto à personagem em lbsen... mas qual personagem? 0 que é uma personagem? Eu, na realidade, desconfio da personagem. Isto agora dava uma conversa...

Era aí que queríamos chegar...

Na encenação da Hedda Gabler, não tive um trabalho exaustivo de mesa. Não cheguei aos ensaios e disse: "A Hedda Gabler é isto e tu, actriz, tens de alcançar isto". Isso 


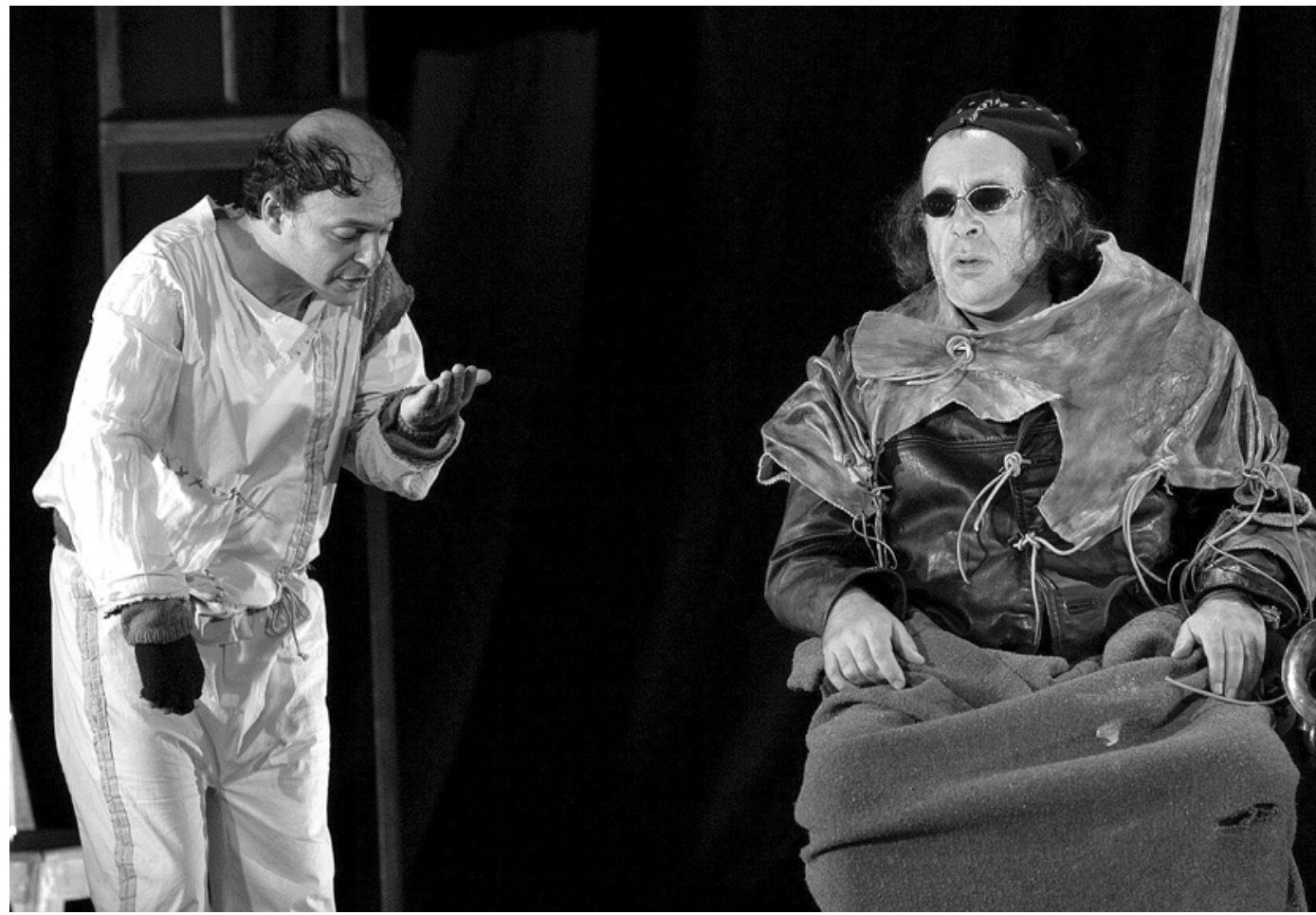

não aconteceu. Por isso posso dizer que o modo como nós, à partida, encarámos o texto do lbsen é igual ao modo como encaramos um texto do Miguel. Agora... é o mesmo que tocar Mozart ou Chopin! Com Ibsen passo a viver com o texto meses antes dos ensaios. Leio e sonho exaustivamente com a peça. Pesadelos, muitas vezes. É esse o meu principal estudo de preparação. No caso da Hedda Gabler fui muito bem acompanhado pela tradução e dramaturgia do João Paulo Esteves da Silva e do Miguel. Preparámos tudo a três. Mas depois com os ensaios é que tudo começou a ficar mais claro. A melhor maneira de se estudar uma peça é fazê-la. Agora, as personagens. Não sei quem é a Hedda Gabler antes dos ensaios e, se Deus quiser, nem depois da estreia. E espero que ninguém do público fique com uma ideia muito definida de quem é a Hedda Gabler, porque isso quereria dizer que falhei.

\section{Não partiste, portanto, da psicologia?}

Não. Não parti de uma preocupação activa em saber "quem é" esta mulher, "quem é" este marido e "quem é" o Brack. Não começámos por aí. Começámos até quase ao contrário. Com o texto, com as palavras: o que é que eu estou a dizer, para quem é que eu estou a dizer e o que é que isto me devolve. E a reflexão veio depois. Também tive a preocupação de não fechar os sentidos do texto. Acho que o grande desafio que estes textos clássicos nos colocam tem a ver com o não serem estanques, não terem um sentido único... senão resolviam-se, não é? E deixavam de ser clássicos: isto já foi feito, qual é o interesse?

0 desafio é o facto de eles "abrirem" imensas pistas. 0 maior desafio da Hedda Gabler (e que eu senti logo ao ler) foi a possibilidade de se "abrir" para uma infinidade de possibilidades, de não dar respostas muito concretas em relação a quem é esta mulher, que situação é esta ou o que é que isto representa. E também é isso o que deve transparecer no espectáculo. Quanto mais os espectadores saírem com visões diferentes, mais bem conseguido está o espectáculo. Mas regressando à comparação, quanto ao Miguel, ele nem pensa nas personagens, a questão da personagem praticamente não existe. 0 que interessa é a palavra, o texto que se ouve. Já em Ibsen há, de facto, uma preocupação de haver alguém, concreto, uma entidade que tem um percurso, que tem uma situação, mas ainda assim com muitas possibilidades...

\section{E a Repartição (2007) é diferente de Menina Júlia (2009) ...}

A Repartição é um coro que às vezes se encontra e outras vezes se divide em várias vozes. Menina Júlia que eu melhor conheço é a da Ana Brandão. Mas nunca Ihe disse "Olha, a menina Júlia é assim." Não, tens de seguir o texto! Aquelas pessoas estão a dizer umas às outras aquelas palavras. 0 trabalho é compreender "como", não tanto "porquê".

\section{Como é que surgiu o coro em Menina Júlia?}

Não me apetecia usar figurantes a cantar e a dançar para recriar a cena em que todos irrompem pela cozinha, na noite de S. João. Por mais que a trabalhássemos soaria sempre a falso e, para mais, não tínhamos tempo nem dinheiro para trabalhar essa cena com figuração. Era preciso encontrar a energia certa, uma 'vertigem' que tivesse ao mesmo tempo um efeito de surpresa. É uma cena fundamental porque representa aquilo que a menina Júlia e o Jean estão a fazer nesse momento. $\mathrm{E}$ o que eles estão a fazer nesse momento não se vê mas podemos imaginar. Criámos uma plateia em frente à plateia do público. 0 coro (cerca de trinta voluntários) sentava-se nessa plateia. Antes de o coro intervir, os espectadores viam a plateia à sua frente como outra plateia, simples espectadores. Ao meio, apenas uma mesa que simbolizava a cozinha. Depois, quando a menina Júlia e o Jean saíam, a plateia da frente (para todos os efeitos, o público) começava a cantar uma canção, acompanhadas pelo João 
O homem da picareta de Miguel Castro Caldas, enc. Bruno Bravo, Primeiros Sintomas, 2004 (Peter Michael e Raquel Dias), fot. Bruno Bravo.

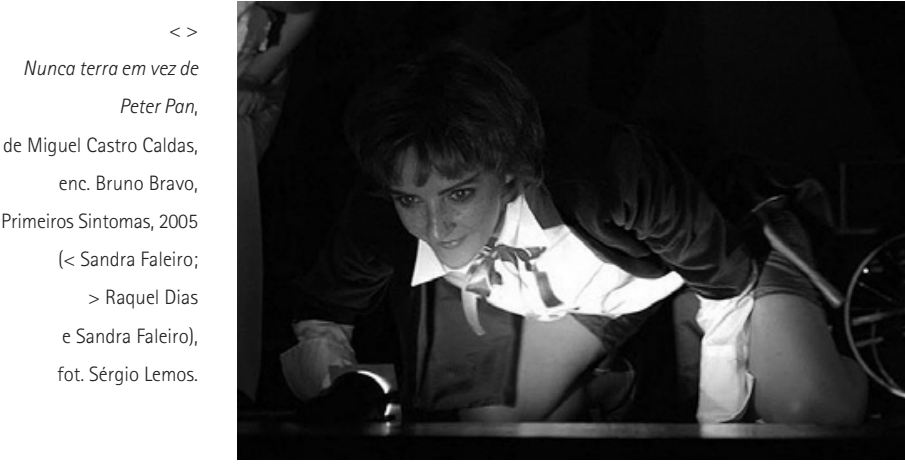

Paulo Esteves da Silva, com um acordeão. Uma canção sobre amores e transgressão cantada de uma maneira muito afinada, muito limpinha, com a mesa da cozinha, nessa altura, vazia em cena. Foi, de facto, um achado muito feliz.

No vosso trabalho de som pode identificar-se o seu uso como meio encantatório, ajudado muitas vezes pela escrita do Miguel.

Acho que o teatro está mais próximo da música do que do cinema, por exemplo. 0 teatro é para ser ouvido. 0 que se vê deve descansar os olhos, para que os ouvidos estejam despertos. 0 tempo de duração de um espectáculo é muito relativo. Há espectáculos de vinte minutos que duram uma eternidade e há espectáculos de três horas que passam a correr. Geralmente o tempo do espectáculo é o tempo do texto. Quando esse tempo é compreendido, tem uma duração específica: nem a mais nem a menos. Os espectáculos de duração mais curta têm coincidido com os textos do Miguel, mas não é pensado, simplesmente acontece assim.... Apetece-me cada vez mais trabalhar em espaços não convencionais. Fui sempre mais feliz em espaços alternativos. Já fizemos muitos espectáculos em teatros convencionais, mas o dinheiro nunca chega para o tamanho do palco. Passo 80\% do processo preocupado com questões de produção.

Foste bastante feliz em Repartição e foi na Culturgest. Com recursos mínimos, porém...

Em Repartição fomos limpando. Limpámos primeiro o movimento dos actores, depois o cenário, depois os figurinos. Resultou num coro, com movimento, confinado ao mesmo espaço. Todos vestidos com uma espécie de ceroulas cor de pele. 0 texto falava de uma menina numa repartição de finanças que não tinha nada a declarar. apenas a sua pele.
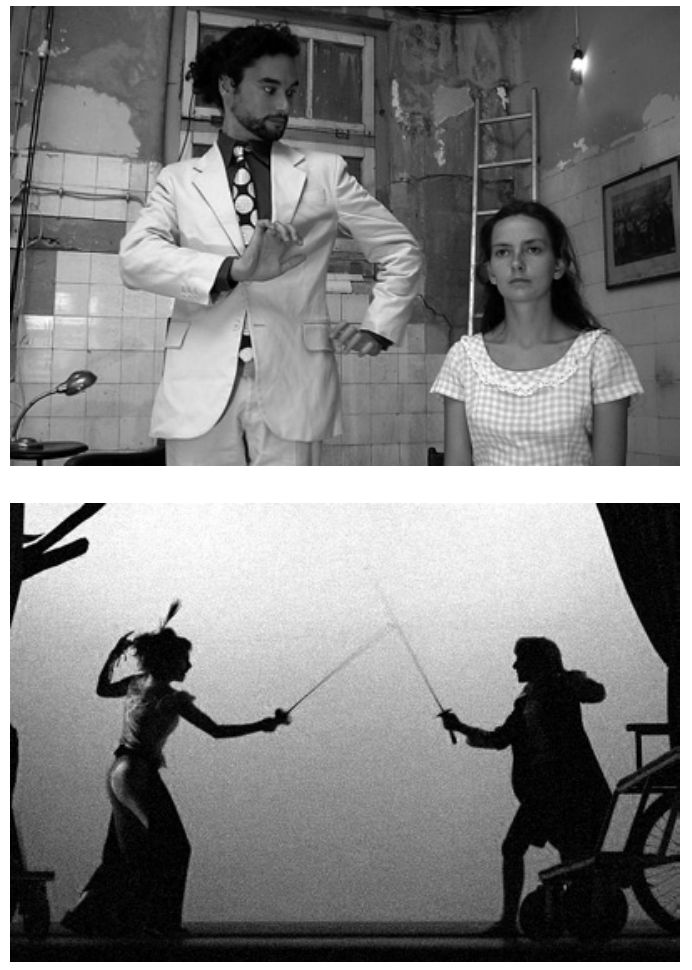

A música e o ritmo permitem criar efeitos encantatórios como nas lengalengas ou nas canções das crianças.

0 que interessa é sempre o conjunto, como é que a minha voz joga com a voz do outro. Por isso os monólogos não me interessam - esta hipótese de em cena se ser absolutamente individual e ao mesmo tempo colectivo é que é importante. A questão da psicologia e da personagem, de que falávamos há pouco, pode tornar os actores egoístas. Tive uma aluna no Conservatório que, quando estávamos a fazer a Electra e eu lhe disse que só podiamos começar a trabalhar em cena depois do texto decorado, se recusou porque primeiro tinha de 'saber' quem era a Electra.

Estava-me a lembrar dos miúdos a brincar. De quando se brinca e, com o embalo, uma coisa leva à outra. Esta cantoria leva a esta, que leva a esta... e vai-se avançando e construindo um território novo (o Deleuze chama-Ihe ritornello). Podia ser um modo interessante de pensar sobre o que vocês fazem com a linguagem... Enfim, 'to play'..

'To play'. 0 teatro é brincar a sério. 0 texto é o guião para esse jogo. Quanto mais complexas forem as instruções mais interessante é o jogo. Por isso é que cada vez me entusiasmam mais os clássicos, e, assim, a andar para trás. Pinter, Beckett, depois Brecht, Tchekov, Ibsen. Gostava muito de chegar a Shakespeare (será possivel fazer Shakespeare em português?), até Ésquilo. Estou a andar para trás. Não sou nada pós-dramático: sou pré-dramático. (Risos)

Percebo o que queres dizer: o "chavão" pós-dramático está muito na moda e tudo o que é "pós" parece ser meio de desconfiar. Mas olha que não sei... com o que já falámos sobre o modo como encaras a personagem psicológica, com este trabalho sobre o texto como palavra, o interesse na coralidade... Tenho a sensação de que estas são características de uma possível 


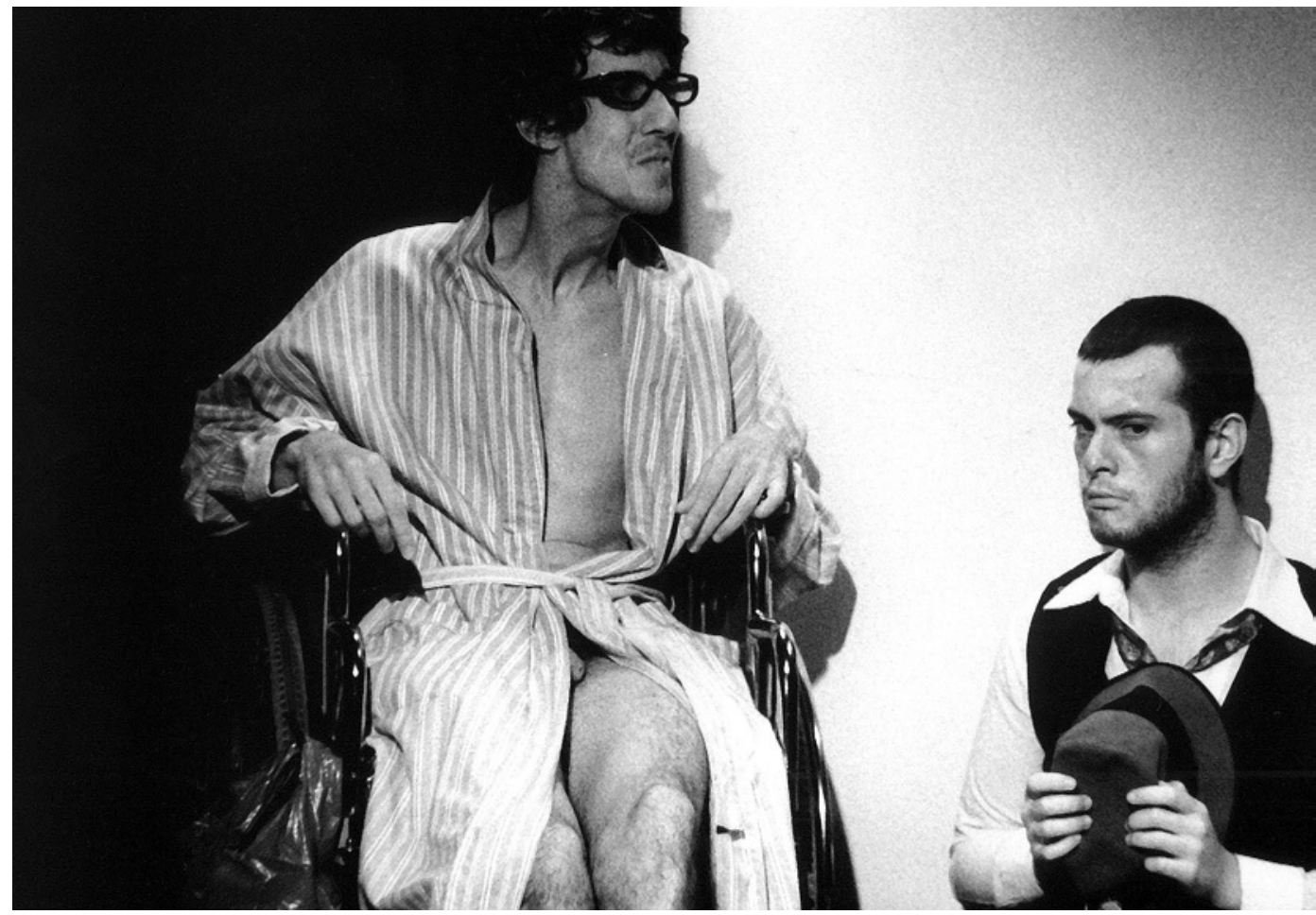

O morto e a máquina, de Fernando Villas-Boas, enc. Bruno Bravo, Primeiros Sintomas, 2006 (< Gonçalo Amorim e Ricardo Neves-Neves: $\checkmark$ Ana Brandão), fot. Kari Jeppesen

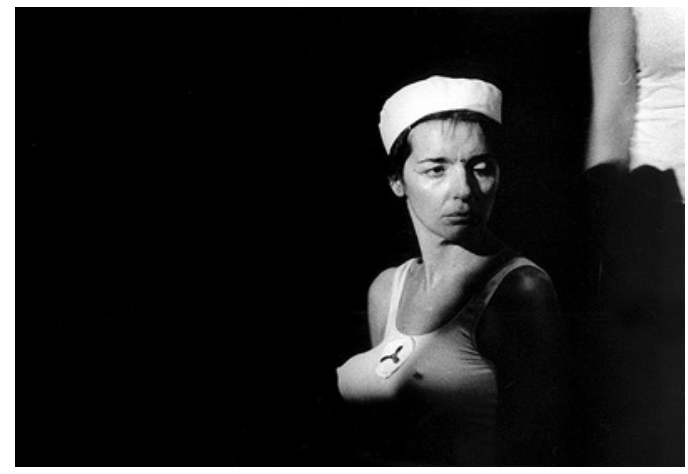

abordagem 'pós-dramática' a textos dramáticos. Aliás, estava a ver a lista das vossas criações e fiquei surpreendida ao encontrar tantas adaptações de textos não teatrais, tantos textos originais $\mathrm{e}$, muitas vezes, um cuidado na tradução de peças que, frequentemente, até já existem traduzidas. Ou seja, sempre uma reinvenção partindo do texto...

0 texto, as palavras escritas, têm sido desde sempre a base do teatro que nos interessa.

Vocês chegam com o "texto dramático" a um tipo de "texto performativo", para usar a expressão de Richard Schechner, que não esconde a sua "teatralidade" e que também não vai no sentido de procurar contaminações com outras linguagens...

Os textos escrevem-se de novo em cena. Em palco são as luzes, os adereços, o cenário, o som, os actores e as personagens que escrevem a cena. Não é possivel fugir às outras linguagens, à pintura, ao cinema, à televisão... porque elas existem e influenciam-nos. Agora, não me passa pela cabeça pegar num texto e perguntar à partida como é que o vou tornar interessante para o público. Com vídeos, dança, música? Partir o texto aos bocados? Isso é contemporâneo, mas eu não sou contemporâneo, só estou vivo, só isso. 0 que me interessa é entrar dentro do texto e ver o que o texto me dá: entrar lá dentro e depois ver até onde aquilo vai.

Vamos voltar a esta ideia do 'brincar' que, a meu ver, é diametralmente o oposto de toda uma lógica realista, a qual mais tarde desemboca, por exemplo, no realismo das novelas... Ou seja, há muito mais formas de brincar do que aos "papás e às mamãs"...

Há sobretudo muitos estereótipos. Ouve-se "vamos fazer um espectáculo à Tchekov", como se houvesse um modelo. E essa ideia de modelo, associada a uma ideia de teatro 'de reportório', leva ao conceito do Tchekov 'limpinho', fazer Tchekov by the book... como se isso existisse. A paranóia da "excelência" na arte, no teatro, em tudo. Ou então dá no seu oposto, que é a negação total de tudo isto, dizer que já não faz sentido fazer-se Tchekov, ou Brecht, colocar todos os clássicos no mesmo saco e rejeitá-los de uma assentada, como se estivessem ultrapassados. Vejo tanto preconceito numa atitude como na outra.

Enfim, e quanto ao primeiro dos estereótipos, o da "excelência", o que mais detesto nessa atitude é o embelezamento. Aquela ideia de que Shakespeare é muito bonito, tem de ser muito bem dito, mesmo que não se perceba nada do que se está para ali a dizer.

E depois há muitas maneiras de encenar. E não conseguimos fugir à influência da televisão e do cinema, que nos moldam absolutamente a cabeça como espectadores e como pessoas. Muito do nosso pensamento é cinematográfico, e acho que o teatro não se deve encostar a isso, acho que é fácil encostarmo-nos a isso, mas não podemos.

Não me parece que tenhas um pensamento particularmente cinematográfico, nem do ponto de vista de uma montagem rápida, nem do ponto de vista das personagens... 


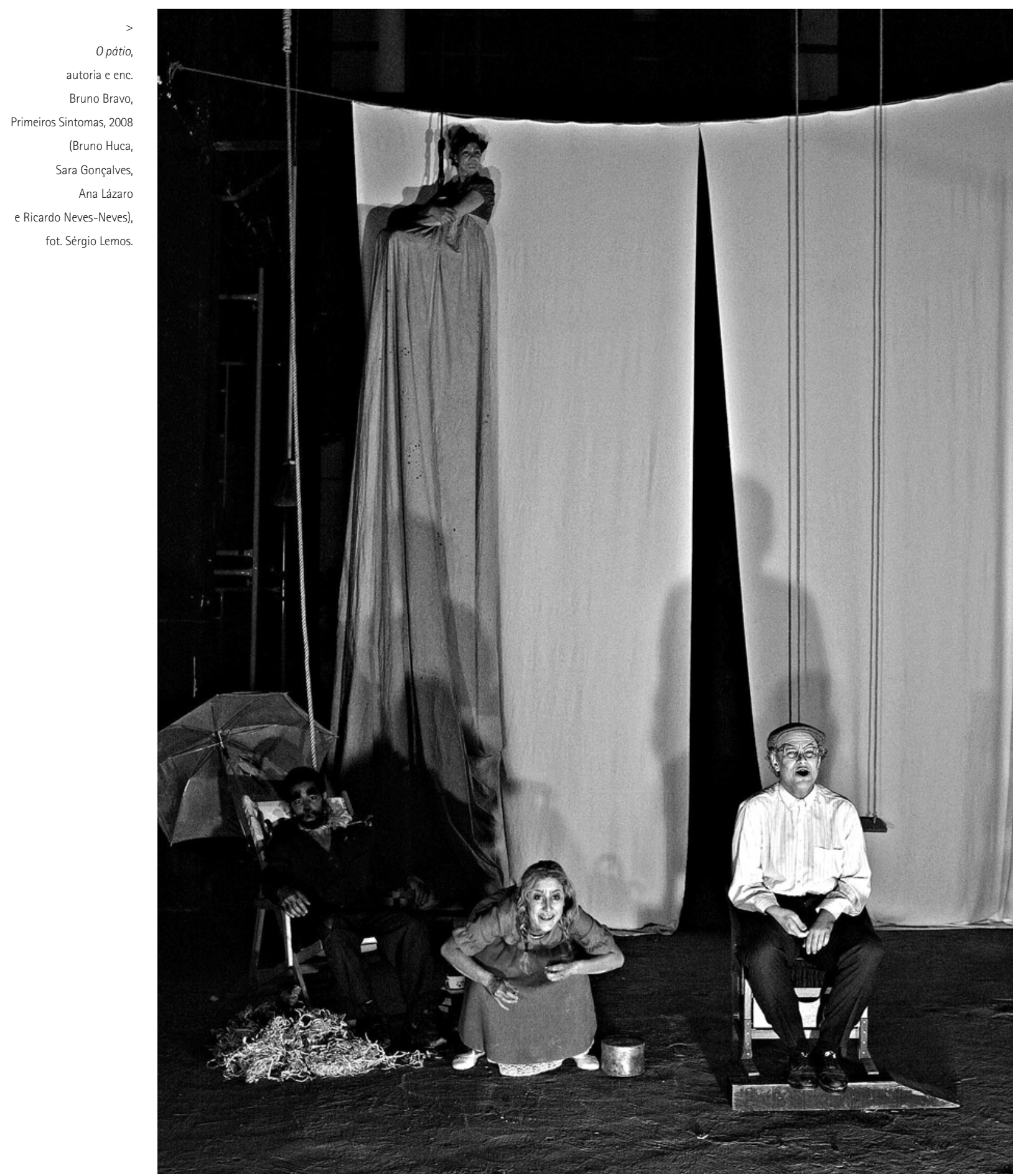

Mas... sabes, inconscientemente, tenho sempre um ideia também cinematográfica dos espectáculos. Dentro da nossa cabeça, quando imaginamos, estamos a montar imagem e som.

Nos teus processos costumas usar muitas referências de livros de artistas plásticos, filmes?

Depende do projecto. Mas não muito. Quando o espectáculo é mais complexo ou exigente a nível plástico, claro.

Vês-te a fazer coisas sem base no texto? Neste momento não estou a pensar nisso, mas o que é que entendes por texto?
Texto, texto. Partir de uma peça ou de um romance ou...

Mesmo que não houvesse texto, tinha de haver um texto invisivel. Eu e o Miguel chegámos a falar sobre isso, a ideia de um espectáculo sem texto, mas escrito.

\section{Com didascálias?}

Sim, com palavras que não são faladas, que descrevem as acções.

Que esperas tu do público?

Penso muito pouco no público. É perigoso pensar no público porque o teatro não existe sem público e é preciso 

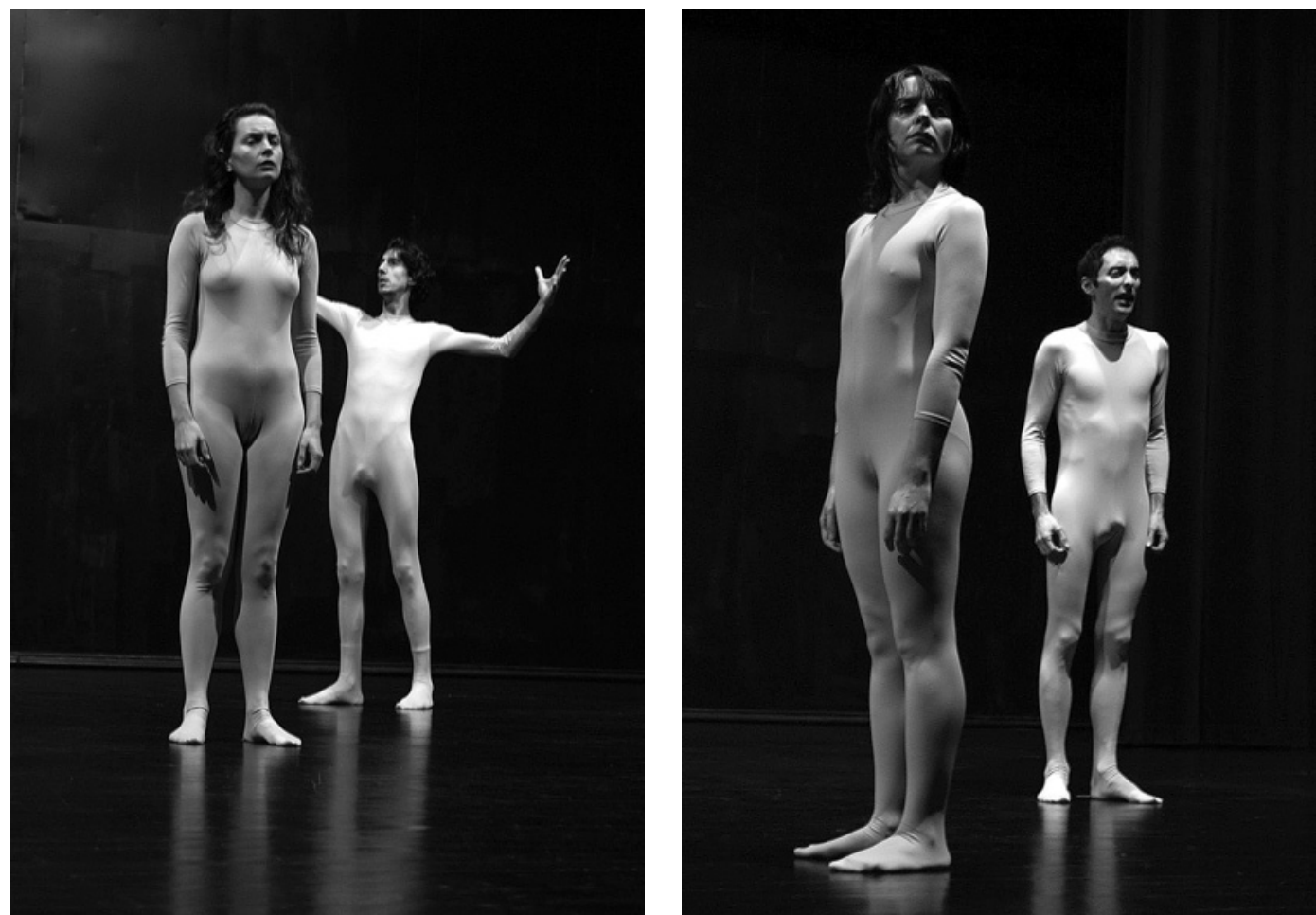

respeitar isso. Começar a pensar num espectáculo que possa agradar ao público é exactamente o mesmo que combinar um café com alguém e pensar no que Ihe vou dizer para the agradar. Perde-se a espontaneidade, ficase condicionado. Não procuro educar o público. 0 público não existe para ser educado. Não gosto que se vá à escola para se ser educado, quanto mais ao teatro. A aprendizagem é um conceito muito subjectivo e um percurso individual. Desconfio da ideia de ligarem o teatro à educação, à pedagogia, desconfio disso tudo.

Falar em educar o público implica acharmo-nos superiores ao público. Provocar é diferente, a relação passa a ser horizontal, é quase uma conversa, não estamos a conversar, mas é uma troca de igual para igual...

É isso. Uma relação horizontal. Mas é sempre uma dialéctica, complexa. 0 que se passa em palco não é só o que o espectador vê e ouve. 0 palco deve ser também um livro, dar espaço à imaginação. Não podemos ter a ilusão ou a pretensão de que o público vai ler exactamente o que the queremos dizer.

E como vês o teu papel na escola, como professor? É uma relação de permanente conflito interior que, à medida que as minhas experiências a dar aulas se vão repetindo, tendo a amenizar. Tenho permanentes dúvidas sobre a Escola como instituição. 0 que se ensina? Como se ensina? Será que faz sentido este termo ensinar? Como se avalia? 0 que é avaliar? Acho que a questão principal é: o que se aprende? Não me vejo como professor no sentido mais estreito do termo. Mais "académico", se quiseres. 0 teatro é uma linguagem cheia de outras linguagens. Eu compreendo a técnica, no teatro, porque é evidente. Mas é um território pouco palpável e muito movediço. 0 teatro não é como a música onde, independentemente dos teus interesses, tens de aprender solfejo. Ou se pensarmos em letras, ou pintura. 0 teatro tem muitas gramáticas, logo na sua base. 0 mais importante tem sido sempre os alunos e o que fica da nossa comunicação uns com os outros. Essa possibilidade de comunicação. Esse entendimento na construção de um objecto. Nesse aspecto não vejo o meu papel de professor muito diferente do que é o meu papel de encenador.

Como definirias hoje os Primeiros Sintomas, passados nove anos de existência e vinte e três espectáculos? Em primeiro lugar, há dois "primeiros sintomas". Há os "primeiros sintomas" que sou eu, na minha cabeça, a imaginar uma companhia, a fantasiar. E depois os verdadeiros Primeiros Sintomas, que são uma equipa imensa, variável. Os Primeiros Sintomas são uma companhia quando tem um espectáculo em cena e uma estrutura de produção quando não tem. Mas o mais aproximado é dizer que são um grupo de teatro, com características especificas. Tem um encenador principal, que sou eu, e uma equipa Para além de alguns dos actores e do Miguel Castro Caldas, há o Stéphane Alberto que é o cenógrafo e o José Manuel Rodrigues que é o homem das luzes. Com o Stéphane existe uma imensa cumplicidade, conhecemo-nos desde sempre, e não me imagino a trabalhar com outro cenógrafo. Com o José Manuel Rodrigues... é impressionante, reúnome com ele para lhe falar do próximo espectáculo, de como o imagino, e ele começa logo ali a desenhar as luzes, às vezes num guardanapo, como já aconteceu num café (risos). Pode parecer improvável, mas connosco funciona. Depois os actores. Tenho uma relação de dependência absoluta com alguns. Gosto de pensar nos Primeiros Sintomas como um grupo de música. Como uma banda em que os músicos vão variando.

Mas em que se mantém um núcleo central? Um núcleo central, sim. Até houve uma altura em que recorrente que é igualmente responsável pelos espectáculos.
$<>$

Repartição, de Miguel Castro Caldas, enc. Bruno Bravo, Primeiros Sintomas, 2008 < $<$ Raquel Dias e Gonçalo Amorim; $>$ Ana Brandão e Bruno Simões), fot. desconhecido. 
pensei em criar uma espécie de conselho de direcção, mas correu muito mal, nunca conseguia reunir as pessoas e desisti. (risos) Mas aquilo que faz a singularidade dos Primeiros Sintomas é que há um pensamento que tentamos que seja colectivo, na maneira como imaginamos a estrutura. Esse pensamento é o resultado do crescimento individual de cada elemento do grupo. Daquilo que cada um de nós pensa sobre o teatro. À medida que eu vou encenando (mesmo peças não escritas pelo Miguel), ou que o Miguel escreve (mesmo peças não encenadas por mim), vamos tendo ideias sobre o teatro e sobre o que queremos fazer, umas vezes mais claras, outras vezes mais difusas, e tudo isso influencia muito o crescimento da estrutura. E o mesmo se passa com todos os elementos da equipa. É complexo, porque a estrutura é uma coisa e nós somos outra, apesar de estarmos ligados...É importante que o crescimento da estrutura não nos limite.

\section{Não vos limite?}

Sim. Prezo muito a liberdade criativa e nisso sou acompanhado por toda a equipa. 0 grande desafio é mantermos o máximo de liberdade criativa possivel lidando com uma estrutura que implica limitações, que tem um custo (o espaço, as pessoas que contratamos e que investem na estrutura, ganhando pouco, mas que de algum modo esperam um retorno) e perceber como é que essa estrutura pode evoluir de maneira a que a liberdade criativa de cada um não fique demasiado prejudicada.

E exactamente como começaram os Primeiros Sintomas? Os Primeiros Sintomas têm uma história que nasceu da vontade de eu encenar e da necessidade de ter uma estrutura que apoiasse as minhas encenações. Os fundadores são a Alejandra Alem, que foi a primeira produtora, a Sandra Faleiro e eu. A Sandra também queria encenar e o nosso propósito foi fazer uma estrutura que produzisse as nossas peças, porém, acabámos por produzir um espectáculo da Carla Bolito (Transfer, 2002), outro do Élvio [Camacho] (As rosas suicidam-se, 2001) e, finalmente, o Frankenstein (2002), encenado por mim. A partir daí evoluiu-se para um princípio mais colectivo, em que comecei a trabalhar com uma equipa de actores bastante recorrente e começou a surgir o tal núcleo central. No fundo, havia uma espécie de investimento daquele grupo de pessoas na estrutura: às vezes, num determinado espectáculo ganhavam mal, mas no outro, a seguir, também participavam e já ganhavam melhor. Era instável, mas mesmo assim havia uma recorrência das mesmas pessoas.

Houve uma altura em que os Primeiros Sintomas estavam directamente relacionados com o Gonçalo Amorim, com o Miguel Castro Caldas e contigo. Em dez anos de existência passámos por muitas fases. É como a tal ideia de banda. 0 Gonçalo foi, e continua a ser, importantíssimo nos Primeiros Sintomas, não só como actor. Connosco encenou o Foder e ir às compras (2007) e comigo o Maria mata-os (2010). Mas o Gonçalo agora está a investir numa carreira a solo (risos). E muito bem. Acho que é um encenador muito importante. Já tem, também, uma equipa que o acompanha. Mas tivemos outros elementos que tiveram um papel de relevo nos Primeiros Sintomas, como foi o caso da Raquel Dias e do Gonçalo Waddington.

\section{E outros projectos?}

Gostava que os Primeiros Sintomas passassem a desenvolver outras coisas, como a edição de textos (muitas traduções e textos representados nunca foram editados), ou mesmo cinema.

\section{Os Primeiros Sintomas já realizaram um filme, não} foi?

Sim, Lianor, de Edgar Feldman, com um texto do Miguel Castro Caldas. Um filme eminentemente "teatral", filmado 


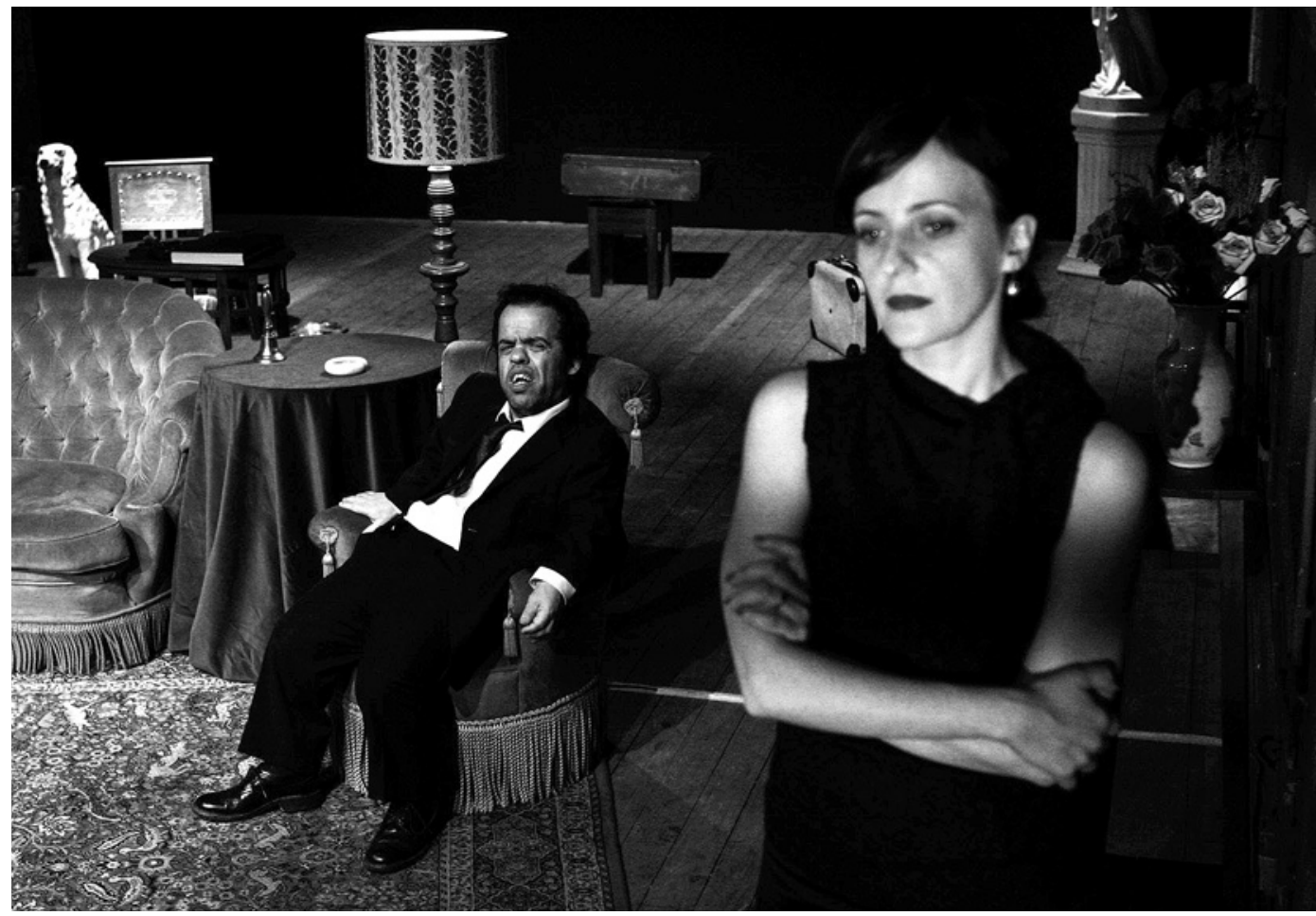

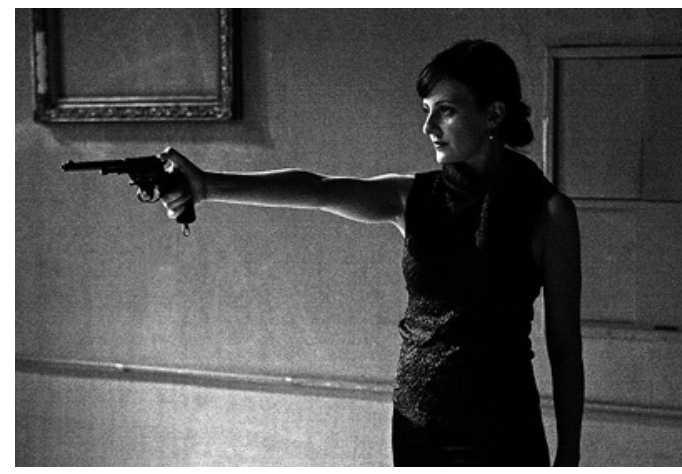

num espaço branco. A minha ideia é reanimar esta ideia da produção de cinema.

Em 2005 quando foste entrevistado para a revista dos Artistas Unidos ${ }^{3}$ sentia-se em ti um grande fascínio por ter sido possível concretizar tanta coisa em tão pouco tempo. Agora, em contrapartida, parece que sentes as coisas a andarem mais devagar. É assim? É natural nessa entrevista sentir-se um certo fascínio porque nós tivemos muita sorte, apanhámos uma boa conjuntura sociopolítica. Somos dos últimos grupos que conseguiu ter apoio sustentado, arriscámos nisso, decidimos ir para o anual e ganhámos o anual, depois o anual foi repetido. As coisas começaram a solidificar-se e, nesse sentido, é justificável o fascínio. Tivemos também bastante apoio da Gulbenkian. Ainda hoje continuo fascinado, mas é diferente, claro. Temos mais responsabilidade, uma estrutura para manter, pessoas que dependem de nós.

E podemos falar em "fases" dos Primeiros Sintomas? Acho que temos passado por várias fases, sim. Dividiria em três fases a evolução dos Primeiros Sintomas. A primeira fase, sem co-produções, em que trabalhámos muito na Associação Abril em Maio, no Regueirão dos Anjos

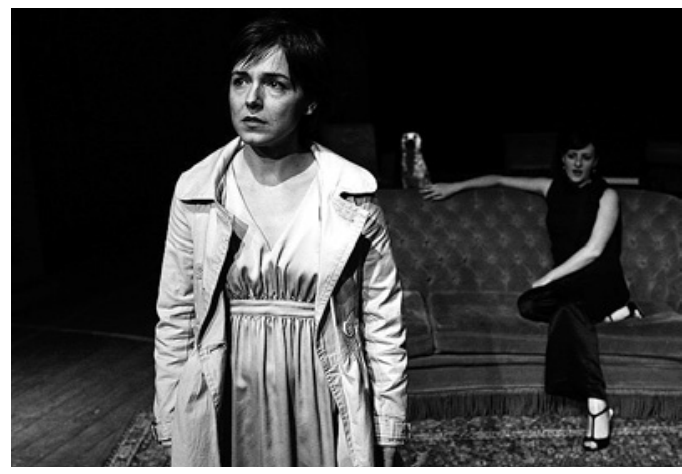

(Frankenstein, Conto de Natal, A montanha também quem, O homem do pé direito) e na Casa Conveniente ( 0 vidro, de Francisco Luis Parreira em 2002). A segunda fase, em que começámos a ter co-produções, primeiro com a Culturgest, que me convidou a mim e ao Miguel para fazermos o Nunca terra (2005); e, passados dois anos, Repartição (2007). Depois com o Meridional, onde fizemos o Endgame (2004), com o Miguel Seabra; depois com o Teatro Maria Matos (Agora baixou o sol, 2007, e Maria mata-os de Miguel Castro Caldas, 2010), depois ainda com o CCB, onde o Gonçalo fez o Foder e ir às compras (2007), que correu muito bem. Finalmente a terceira fase, a do espaço próprio - A Ribeira.

E as duas trilogias que fizeram onde se encaixam? A "trilogia do cão" ( $O$ morto e a máquina de Fernando Villas-Boas, Erva vermelha, a partir de Boris Vian, e Timbuktu, a partir de Paul Auster) e a trilogia Menina Júlia, Hedda Gabler e Lindos dias? Como apareceu essa ideia e como escolhem vocês o reportório?

A "trilogia do cão" foi pensada desde o início como trilogia. Três espectáculos que tivessem um cão como personagem. Pensámos na Erva vermelha (2006) do Boris Vian (uma das personagens é um cão que fala) e convidámos a $\wedge$

Hedda Gabler, de Henrik Ibsen, enc. Bruno Bravo, Primeiros Sintomas, 2009 ( $\wedge$ David Almeida e Sandra Faleiro $<$ Sandra Faleiro; $>$ Anabela Brigida e Sandra Faleiro) fot. Sérgio Lemos.
AA.W., 'Primeiros Sintomas: Um luxo', in Dossier "Os que andam por ai afirmando-se", Revista dos Artistas Unidos, n. 13 , Março 2005. 


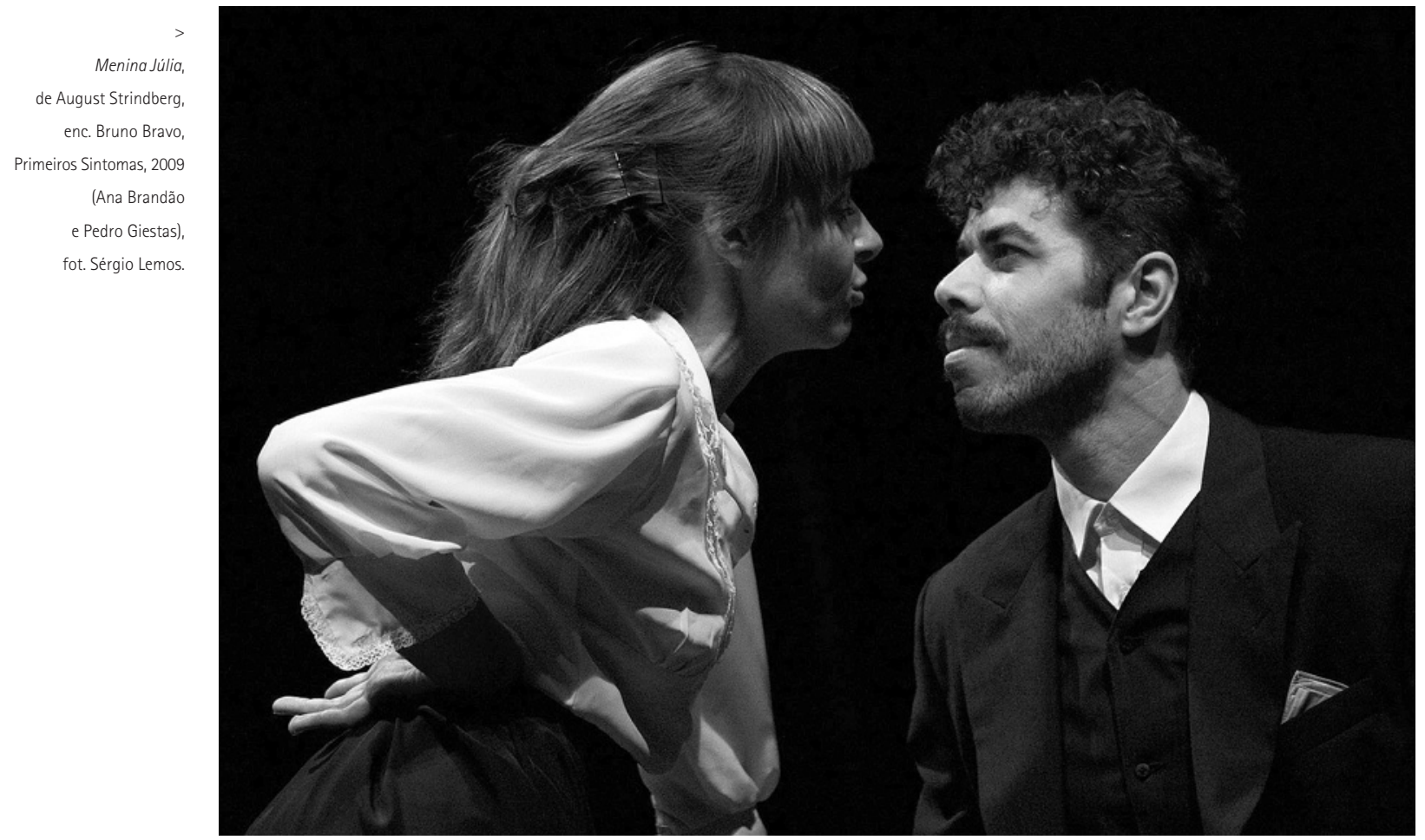

Cristina Carvalhal para a adaptar e encenar. Depois a Sandra Faleiro escolheu o Timbuktu (2006) do Paul Auster e encenou a adaptação da Emília Costa. Eu convidei o Fernando Villas Boas para escrever uma peça de ficção científica, 0 morto e a máquina (2006). Não sei de onde apareceu esta ideia do cão. Foi uma daquelas coisas... apareceu... pronto. No entanto, guardo recordações incriveis dessa produção. Estivemos na sala estúdio do Trindade, sempre esgotada. Juntando as três peças acabou por ser uma equipa imensa. Foi muito especial. A trilogia Ibsen, Strindberg e Beckett, não foi pensada no início como trilogia. Aconteceu programarmos os três espectáculos de seguida, sempre no Negócio/ZDB em 2009/2010. Todas as peças têm personagens femininas em primeiro plano. o Miguel Castro Caldas e o João Paulo Esteves da Silva traduziram os três textos. Alguns actores continuavam de uma peça para a outra. Aproveitámos para divulgar os três espectáculos como se constituíssem um todo.

As fases que indicas estão mais ligadas a condições externas (modo de financiamento, espaço) do que a evoluções estéticas. Isso faz-te alguma impressão.. É verdade, Miguel (Castro Caldas)! Nesta divisão preocupeime mais com os aspectos da produção, com a estrutura. Mas em termos estéticos, houve uma fase em que ainda não trabalhava com o Miguel e me dedicava sobretudo a adaptações literárias. Foi nessa altura que fiz a adaptação do Frankenstein de Mary Shelley. Depois houve a fase de trabalhar com o Miguel, com os textos do Miguel, o que ainda se mantém. E agora, talvez, para além dos textos

${ }^{4} 0$ titulo corresponde a uma nova tradução da peça Happy Days, de João Paulo Esteves Silva, esteve na base do do Miguel, a vontade de encenar os grandes dramaturgos: Ibsen, Strindberg, Beckett, Brecht...

Mas as condições financeiras são sempre fundamentais... Pois são. É preciso dinheiro para pagar às pessoas, para fazer os cenários, os figurinos, etc. E dependemos todos dos subsídios que, na verdade, não são subsídios nenhuns, mas sim um concurso público, e isto é muito importante que se diga, pois é preciso participar num concurso público preencher um número indeterminado de requisitos para se ter direito a um subsídio, não basta dizer-se que se é artista. E depois temos de apresentar os espectáculos e procurar as melhores soluções apesar do pouco dinheiro que se recebeu. De qualquer modo, é uma pena que os subsidios se traduzam apenas em dinheiro. Andamos há anos a discutir números, uns com os outros: eu tive vinte mil, precisava de trinta, o outro teve cem mil, para o ano vamos ter noventa mil. É esgotante. Não saímos disto. 0 apoio do Estado devia ser muito mais estrutural, traduzirse em divulgação, em espaços de ensaios e apresentação de espectáculos, em materiais técnicos, e pôr em funcionamento um mecenato que realmente funcionasse.

E mantinham-se os subsídios, aliás, os concursos públicos?

De uma coisa eu tenho a certeza: o teatro não se consegue pagar a si próprio, e pensar de outro modo é perigosíssimo pois nesse caso entra-se na lógica comercial, e o fundamental já não são as escolhas estéticas, mas sim as escolhas que se prevê que irão cativar o público, encher os teatros. 0 teatro não existe para estimular a economia mas para estimular o pensamento. É mais importante que se arrisque, que se erre, que se faça mau teatro, até se chegar a algo inovador, criativo. Isso mais do que apenas procurar fazer o já feito, o consensual, o que se pensa que dá dinheiro. É por causa dessa visão comercial que cada vez se dá mais importância ao programador do que ao criativo. Eu já tive programadores que não aceitaram os Lindos dias, de Beckett ${ }^{4}$, porque era um espectáculo muito complexo e depois não enchia os teatros porque as pessoas não o compreendiam. Mas o importante não é os teatros encherem: o importante é a diversidade, é tu abrires o jornal e poderes escolher. 


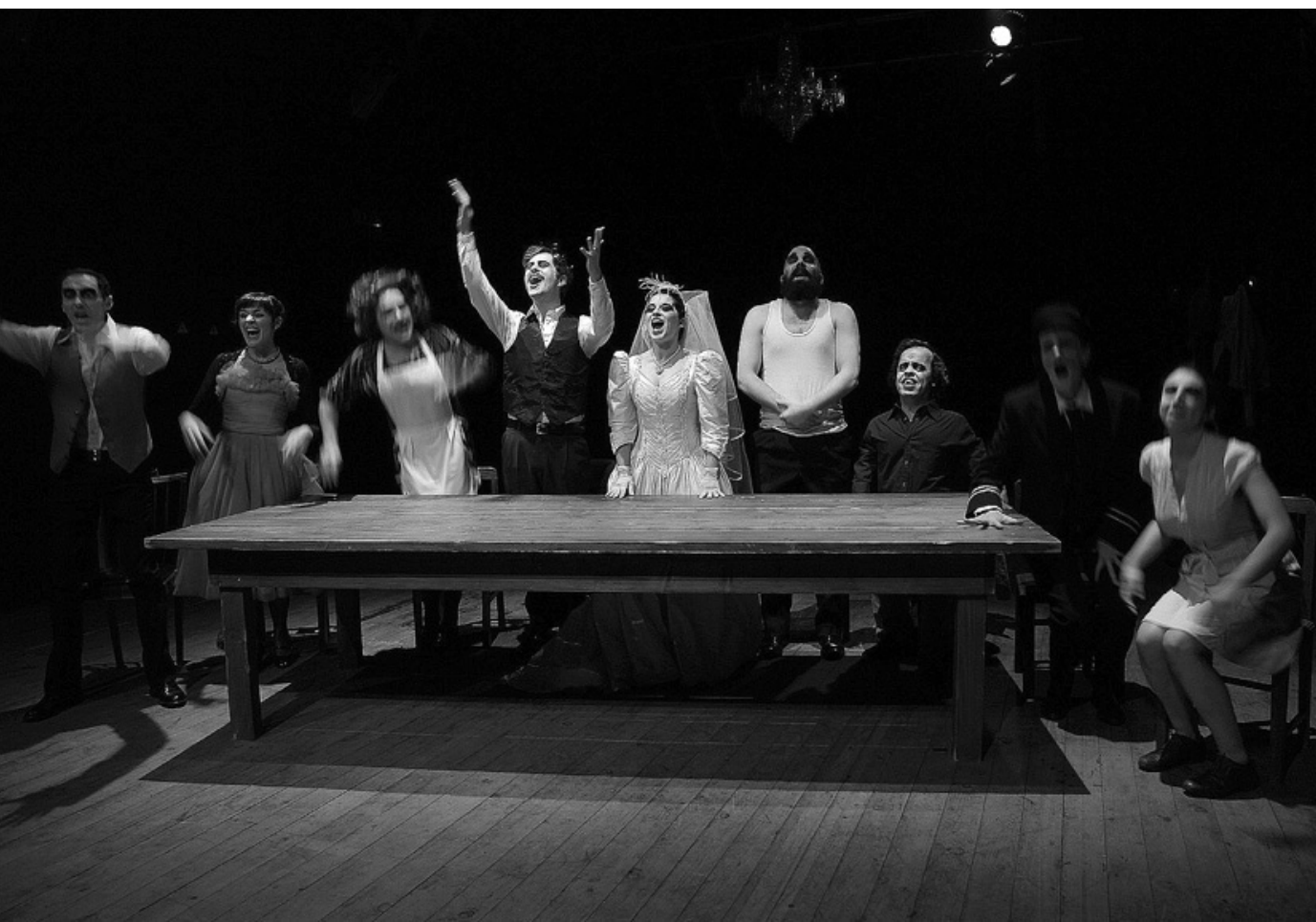

Então os subsídios/concursos, são necessários? 0 que é necessário é o apoio. 0 concurso público não devia resultar só em dinheiro e o dinheiro não devia sequer ser o mais importante. Anúncios gratuitos nas televisões, cedência de espaços sem pagamento de renda, apoio material, clarificação das leis que nos regem, tudo isso era muito mais importante do que apenas o dinheiro. $\mathrm{E}$ isso fomentava muito mais a autonomia dos grupos. Se nos tiram tudo (como está a acontecer), ao menos que nos deixem os meios para conseguirmos ser autónomos. Meios, ferramentas. Mas claro que o apoio para se fazer espectáculos é necessário.

\section{Falaste em leis...}

As leis que regem os espaços alternativos são muito pouco claras e não facilitam a nossa actividade. A impressão que dá, uma vez mais, é que a política cultural é a política dos números e apenas procura proteger os teatros nacionais e municipais, onde se faz alegadamente "teatro convencional", por oposição ao "experimental". Eu não sou "experimental", eu faço espectáculos de teatro.

0 que é que o espaço próprio, a Ribeira, que já existe há um ano, trouxe de novo aos Primeiros Sintomas? Tudo mudou. Agora os Primeiros Sintomas têm o seu espaço próprio e já não se imaginam sem a Ribeira. Claro que o montante do subsídio até encolheu e o encargo agora é muito maior. $E_{1}$ na verdade, a Ribeira tem funcionado muito mais como espaço de acolhimento do que como espaço próprio. Tirando o Festival Curtas (Mostra Teatral de Peças de Curta Duração, Julho 2010) e as Leituras não encenadas (Julho 2011), ainda não conseguimos produzir nenhum espectáculo nosso. Estamos presos a co-produções. 0 drama é esse: dependemos das co-produções. Não podemos fazer As bodas de Fígaro na Ribeira. Não só por o espaço ser demasiado pequeno, como também por não termos dinheiro para pagar aos actores. É um pouco irónico: termos um espaço próprio que cedemos a outros grupos, porque não conseguimos produzir nele os nossos espectáculos. Mas este ano, em Maio, vamos finalmente estrear a Salomé, de Oscar Wilde, que vai ser a nossa primeira produção no nosso espaço.

\section{E como é que conseguem?}

É um espectáculo apenas com três actores e o objectivo é a itinerância. Estreamos na Ribeira e depois vendemos o projecto pelo pais fora. Só assim é que conseguimos.

\section{Os Primeiros Sintomas costumam circular muito?}

Não muito. É difícil vender. Depois os nossos espectáculos costumam ter equipas grandes, o que não facilita. Tivemos um espectáculo mais pensado para a itinerância, $A$ montanha também quem (2003), de Miguel Castro Caldas, que circulou por alguns sítios. Depois o Endgame, fez uma itinerância pelo pais muito grande, também com o apoio do Teatro Meridional, co-produtor do espectáculo. Fizemos a Hedda Gabler em Guimarães. Com os Lindos dias fomos ao Rio de Janeiro, e pouco mais.

\section{Pretendes que haja uma utilização quotidiana da} Ribeira?

Gostava muito que fosse um espaço que não parasse. Um concerto à quarta-feira, um espectáculo à quinta, outro à sexta, no sábado outro ainda. E também cinema, exposições, conversas. Todos os dias, ou quase todos os dias, preenchida com múltiplas actividades.

E que ligações tem a Ribeira com os outros espaços teatrais que existem no Cais do Sodré? Já pensaram em fazer coisas juntos?

Acho que seria muito interessante aproveitarmos esta proximidade. Tenho esperança que este ano no projecto Curtas possa existir a participação de outros grupos. 
As Curtas e as Leituras são um espaço muito específico de criação artística experimental que, no seu limite, me fizeram lembrar os LAB do João Fiadeiro, nos anos 90, ainda na Malaposta. Ou o que me contaram sobre como nos LAB havia um clima de real experimentação. Qual é a tua ideia sobre estes dois projectos? São dois projectos que me são muito caros. As Leituras não encenadas aconteceram pela primeira vez este ano. Cerca de cinquenta actores, que leram catorze peças, sem as ensaiar previamente, ao longo de três semanas. 0 Festival Curtas Primeiros Sintomas é bienal e vai para a terceira edição em 2012. É uma experiência importante, sobretudo para o público, que pode assistir num dia, numa hora, a cinco espectáculos completamente diferentes uns dos outros. Cada festival tem cerca de catorze espectáculos, quase todos com 15 minutos, com textos e criadores diferentes. Desde alunos de teatro que começam a fazer as primeiras experiências, ao Miguel Moreira, ou ao Ricardo Aibéo, por exemplo. Foi nas Curtas de 2008 que o Miguel Castro Caldas se estreou como actor, num espectáculo encenado pelo Stéphane Alberto, o nosso cenógrafo

As Leituras foram uma espécie de 'corpo-a-corpo' teatral. Era a primeira vez que os actores se encontravam e estavam a ler o texto?

Sim. É um projecto que exige muita criatividade por parte dos actores e que é também muito arriscado para o público. Nas Leituras houve momentos incriveis e momentos um bocadinho mais difíceis, dependendo do texto e da inspiração do momento. Mas acho que, de uma maneira geral, correu muito, mesmo muito, bem. A maioria das reacções foi entusiasta, mas também houve reacções do género "mas para que é que isto serve?" (risos)

\section{Envolveu muitos actores?}

Sim, cerca de 40 actores. E foi uma maneira também de experimentarmos textos. Nas Leituras houve determinados textos, mais uns do que outros, que só cabiam ali e foi uma maneira de os ouvirmos. Por exemplo, não imagino fazer uma produção do Octávio, de Victoriano Braga, e, no entanto, foi incrivel: eu adorei essa Leitura, e acho que aquele foi o espaço adequado para aquele texto, que só podia resultar naquelas condições e isso é muito interessante. 0 mesmo se passou com a Gina (uma adaptação para teatro de uma história publicada no primeiro número da revista Gina): só ali é que aquele texto podia funcionar. E nós, Primeiros Sintomas, criámos um espaço onde é possivel que aconteça este tipo de coisas. Acho isso muito positivo.

\section{E não só conseguem reunir tantos actores como eles} aceitam não receber.

Dinheiro. Não. Pois, isso não recebem. E sim, tudo isso é fantástico. 0 público também não paga para entrar.

As Leituras criaram, então, "comunidade", quando se apela à desconfiança e ao salve-se-quem-puder. 0 mérito está todo nas pessoas que colaboram nestes eventos e que a eles se dedicam verdadeiramente. É claro que também é verdade que as pessoas estão sedentas, querem fazer coisas, trabalhar, inovar e não há muitos espaços que Ihes permitam isso, não há.

\section{Referências bibliográficas}

AA.W., 'Primeiros Sintomas: Um luxo', in Dossier "Os que andam por ai afirmando-se", Revista dos Artistas Unidos, n. ${ }^{\circ}$ 13, Março 2005. DELEUZE, Gilles / GUATTARI, Félix (1997), Mil platôs: capitalismo e esquizofrenia, vol. 4, trad. Suely Rolnik, São Paulo, Ed.34

\section{Nota}

Parece poder dizer-se que em Lisboa (ou mesmo em Portugal) há pouca tradição de espaços duradouros de 'contracultura', poucos lugares de experimentação fora das pressões do mainstream (mesmo que do mainstream 'alternativo'), embora ciclicamente eles apareçam. Se, no inicio da sua existência, a ZBD correspondeu a um esforço para colmatar essa falta, pode dizer-se que actualmente este espaço se encontra num estado intermédio, sendo o lugar onde se incentiva a produção e se apresenta o que é alternativo mas já de reconhecida qualidade institucional. Por outro lado, nos últimos anos, têm vindo a aparecer estruturas de experimentação artistica despreocupada, como o espaço dos Primeiros Sintomas, ou espaço sociais como a Casa da Achada, a Da Barbuda, na Mouraria, o RDA69, nos Anjos, ou mesmo a Fábrica de Braço de Prata e o Bacalhoeiro, entre outros. Destes lugares, sobretudo dos últimos, deve sublinhar-se a dependência económica do bar que os transforma principalmente em lugares da noite - onde se apresenta, mas raramente se ensaia, por onde passa muita gente, mas ninguém está em permanência. Para um entendimento das novas sociabilidades da cidade de Lisboa e mesmo de algumas novas propostas estéticas é necessário ter em atenção a emergência destes espaços e a sua utilização como espaço de ensaio e de apresentação de performances, espectáculos e afins. 